\title{
Jeszcze raz w sprawie dzialalności Piotra i Mikolaja Komorowskich na Górnych Węgrzech w XV wieku
}

Połowa XV wieku była w historii Górnych Węgier, obejmujących w przybliżeniu tereny dzisiejszej Słowacji, czasem działań tzw. bratrzyków, czyli zorganizowanych na podobieństwo ówczesnych wojsk grup uzbrojonych ludzi zajmujących się działaniami o charakterze rozbójniczym ${ }^{1}$. Wśród osób uważanych za ich przywódców byli dwaj polscy możni: Piotr i Mikołaj Komorowscy. Ich działalność była już tematem publikacji naukowych, z których najważniejsze to dwa artykuły krakowskiego historyka Grzegorza Żabińskiego². Niniejszy tekst stanowi próbę uzupełnienia i korekty tego dorobku naukowego m.in. poprzez uwzględnienie nowszych badań historycznych czy też szersze omówienie niektórych źródeł ${ }^{3}$.

${ }^{1}$ Husiti a bratríci na Slovensku. Ed. P. Žarnovský. Červený Kláštor-Kežmarok-Stará Lubovňa 2016; J. Špirko: Husiti, jiskrovci a bratríci v dejínách Spiša (1431-1462). Spišská Kapitula 1937; F. Oslanský: The Role of John Jiskra in the History of Slovakia. "Human Affairs" 1996, no 6, s. 19-33.

${ }^{2}$ G. Żabiński: Działalność braci Piotra i Mikołaja Komorowskich na Górnych Węrzech $w$ latach 1440-1457 (w świetle badań w Archiwum Bardowskim). St. Hist. 2000, nr 43, s. 3-25 (dalej: Działalność w latach 1440-1457); Tenże: Działalność braci Piotra i Mikołaja Komorowskich na Górnych Wegrzech w okresie rząów Macieja Korwina. W: ZNUJ. Prace historyczne, nr 128. Kraków 2001, s. 79 -91 (dalej: Działalność w okresie rząów Korwina); tam podana starsza literatura.

${ }_{3}$ Materiały pochodzące z zasobów Węgierskiego Archiwum Narodowego w Budapeszcie (Magyar Nemzeti Levéltár) dalej oznaczone zostały skrótem: MNL OL, odpowiednio z sygnaturą: DL (Dilpomatikai Levéltár) bądź DF (Diplomatikai Fényképgyüjtemény). Materiały 
W historiografii ustalił się pewien pogląd na temat pochodzenia rodzinnego omawianych Komorowskich. Mieli oni urodzić się na początku XV wieku, pochodzić z ruskiego rodu Korczaków, ich ojcem miał być pochodzący z Komorowa w ziemi bełskiej Stanisław, syn Dymitra. Mieli oni mieć jeszcze jednego brata - Marcina, oraz trzech bratanków: Jakuba, Wojciecha i Pawła. Przedstawione ustalenia pochodzą z archaicznej dziś pracy Adama Bonieckiego, a opierają się w znacznej mierze na przekazie pamiętnika rodowego Komorowskich, pochodzącego z roku 1706, dlatego też ich wartość wydaje się wątpliwa ${ }^{4}$. Z wymienionych krewnych Komorowskich tylko Marcin został potwierdzony w innych źródłach ${ }^{5}$, znani są za to inni Komorowscy współcześni Piotrowi i Mikołajowi. W aktach grodzkich halickich trzykrotnie w latach 1446-1454 pojawia się Jan Komorowski ${ }^{6}$, zaś w styczniu roku 1447, w czasie gdy Piotr i Mikołaj Komorowscy przebywali na Węgrzech, w aktach tego sądu pojawia się wzmianka o kilku anonimowych Komorowskich?

W starszej, dziewiętnastowiecznej historiografii słowackiej istniało przekonanie, że Piotr Komorowski przybył po raz pierwszy na Węgry jeszcze w okresie panowania Zygmunta Luksemburskiego, jako zaciężny żołnierz w czasie kampanii przeciwko Turkom w 1437 roku. Komorowski miał być obok Jana Jiskry dowódcą najemnej armii złożonej z Czechów i Morawian ${ }^{8}$. Tezę tę powtarza, chociaż z zastrzeżeniem: „podobno”, również G. Żabiński9. Narracja ta była budowana na podstawie siedemnastowiecznej kroniki Mars Moraviensis autorstwa Tomáša Pešina z Čechorodu, ale jako że jest to źródło zbyt późne dla omawianych wydarzeń, należy uznać jego niewiarygodność ${ }^{10}$.

Pierwszy pewny ślad działalności publicznej omawianych Komorowskich przypada w źródłach na marzec roku 1436, kiedy to Mikołaj uczestniczył jako rozjemca w sporze Jaksy, wielkorządcy biskupa Oleśnickiego, z Bartoszem

te zostały wykorzystane za pośrednictwem witryny https://hungaricana.hu/ [data dostępu: 1.11.2020].

${ }^{4}$ A. Boniecki: Herbarz polski. Wiadomości historyczno-genealogiczne o rodach szlacheckich. T. 9. Warszawa 1907, s. 1-2; F. Kiryk: Komorowski Mikołaj. W: PSB, T. 13, s. 423; Tenże: Komorowski Piotr. W: PSB, T. 13, s. 427; S.A. Sroka: Komorowscy z Żywca. Przyczynki genealogiczne z XV wieku. „Gronie: historia — kultura — sztuka: wydawnictwo poświęcone Żywiecczyźnie i Beskidom” 2006, nr 1, s. 45.

5 J. Špirko: Husiti, jiskrovci a bratríci..., s. 51-52.

${ }^{6}$ AGZ, T. 12, s. 151, 158-159, 238.

7 Tamże, T. 4, s. 155.

${ }^{8}$ H. Jireček: Ján Jiskra z Brandýsa. „Slovesnost““ 1865, 3, s. 362-364; S. Hyroš: Zamok Lykava a jeho pani, pot’ahom na državie, Lyptov a okolie. Martin 1876; F. Sasinek: Slovanski válečníci v Uhorsku XV-XVII. storočia (Ján Iskra). „Letopis Matice Slovenskej“ 1872, roč. 9, č. 1, s. $5-6$.

9 G. Żabiński: Działalność w latach 1440-1457, s. 4.

10 Tomáša Pešina z Čechorodu: Mars Moravicus. Praha 1677, s. 610. 
z Cichowa ${ }^{11}$. Późniejsza jego działalność dotyczyła już udziału w wojnie o tron węgierski między królem polskim Władysławem III Jagiellończykiem a próbującą zabezpieczyć tron dla jeszcze nienarodzonego Władysława Pogrobowca królową Węgier Elżbietą. Udział Mikołaja w tym konflikcie został opisany przez Jana Długosza ${ }^{12}$. Ten fragment przekazu krakowskiego kanonika jest uznawany za stosunkowo wiarygodny. Mikołaj początkowo wsławił się utrzymaniem dla Jagiellończyka Podolińca przed dowodzącym wojskami Elżbiety Janem Jiskrą z Brandysa, wspólnie z Mikołajem Czajką Jaworskim atakował posiadłości wrogów Jagiellończyka. W maju 1442 roku dostał się do niewoli po nieudanym ataku na Preszów, a oswobodzony został już po śmierci Jagiellończyka ${ }^{13}$. Więcej wątpliwości budziła w historiografii sprawa rzeczywistej funkcji Mikołaja Komorowskiego na Spiszu i posiadania przez niego zapisów na dobrach królewskich. Feliks Kiryk negował przekaz Długosza, według którego Mikołaj Komorowski miał być podstarostą (inaczej faktorem) Lubowli, działającym z ramienia biskupa Zbigniewa, któremu król miał zastawić całość dóbr spiskich. F. Kiryk twierdził, że Komorowski posiadał zastawy na Spiszu bezpośrednio od króla oraz że otrzymał w roku 1440 tytuł starosty spiskiego $^{14}$. Sprawę tę jednak wyjaśnił, po gruntownej analizie późniejszych sporów Komorowskiego z biskupem, G. Żabiński, ustalając, że Mikołaj był tylko faktorem $\mathrm{z}$ ramienia Oleśnickiego, chociaż istnieje prawdopodobieństwo posiadania przez niego jakichś zapisów od króla na majątkach Lubowli ${ }^{15}$. Nie wiadomo dokładnie, kiedy Mikołaj Komorowski zyskał potencjalne zastawy na Spiszu czy też kiedy zaczął pełnić funkcję podstarosty, znane jest jednak pismo z 5 maja 1440 roku, w którym wspomina się, anonimowo, dwóch urzędników Oleśnickich w Lubowli i Podolińcu - Mikołaj Komorowski mógł być jednym z nich ${ }^{16}$.

Według węgierskiego kronikarza Jánosa Thurócziego Piotr Komorowski miał przybyć na Węgry w roku 1440 jako jeden z dowódców armii Jana Jiskry ${ }^{17}$. Zarówno G. Żabiński, jak i F. Kiryk odrzucili ten przekaz, twierdząc, że Piotr Komorowski przybył na tereny Górnych Węgier razem z Mikołajem i od początku angażował się militarnie po stronie polskiego króla Władysława III Jagiellończyka, czemu miał zawdzięczać rozwój swojej kariery w czasie rzą-

${ }^{11}$ SPPP II, s. 422; F. Kiryk: Komorowski Mikołaj..., s. 427; G. Żabiński: Działalność w latach 1440-1457, s. 5.

12 Annales, lib. 11-12, s. 266, 271-273.

13 J. Dąbrowski: Władysław I Jagiellończyk na Węgrzech (1440-1444). Oświęcim 2014, s. 83-84; Rozbiór krytyczny Annalium Poloniae Jana Dlugosza z lat 1385-1444. T. 1. Oprac. S. Gawęda, pod kier. J. Dąbrowskiego. Wrocław 1961, s. 327.

${ }^{14}$ F. Kiryk: Komorowski Mikołaj..., s. 427.

15 G. Żabiński: Działalność w latach 1440-1457, s. 5-6, 11.

16 Supplementum analectorum terre Scepusiensis. Pars 2. Coll. M.S. Chmauk. Szepesváraljae 1889, no 153, s. 269.

${ }^{17}$ Kronika Jána z Turca. Preložil J. Sopko. Bratislava 2018, s. 543-544. 
dów polskiego króla na Węgrzech ${ }^{18}$. Tak jednoznaczne odrzucenie przekazu w miarę bliskiego świadka opisywanych wydarzeń wydaje się z kilku względów niezasadne. Co prawda mało prawdopodobne, by Piotr jako polski możny ryzykował otwarte działania militarne przeciwko własnemu królowi, należy jednak mieć na uwadze, że zgromadzenie siły militarnej przez Elżbietę Luksemburską nie oznaczało jeszcze początku wojny domowej, która wybuchła dopiero w momencie, gdy Władysław III Jagiellończyk zdecydował się kontynuować swoją wyprawę na Budę, jest więc możliwe, że Piotr rzeczywiście przybył na Węgry z Jiskrą, jednak w momencie rozpoczęcia walk zmienił stronę konfliktu. Piotr Komorowski nie byłby zresztą jedynym możnym, który będąc w służbie królowej Elżbiety, w momencie, gdy ta dopiero zbierała swoją armię, w chwili wybuchu wojny z Jagiellończykiem przeszedł na stronę polskiego monarchy. W bardzo podobny sposób zachował się węgierski szlachcic Pangracz ze Svätého Mikuláša ${ }^{19}$. Nawet jeśli samo przybycie w armii Jana Jiskry mogło zostać źle odebrane przez polski dwór, należy mieć na uwadze łagodną politykę Władysława III Jagiellończyka, który kierując się pragmatyzmem, często przebaczał tym, którzy początkowo wspierali jego wrogów ${ }^{20}$.

W roku 1441 Piotr Komorowski był już na służbie żupana turczańskiego i orawskiego Mikołaja Balickiego, popierającego Władysława III Jagiellończyka na Węgrzech, do końca panowania polskiego monarchy osiągając funkcję podżupana orawskiego - awanse te zawdzięczał raczej protekcji Balickiego niż królewskiej łasce ${ }^{21}$. W roku 1443 Piotr sądził się w Krakowie z chłopem imieniem Romey, skarżąc go o samowolne opuszczenie dóbr, co świadczy o tym, że Piotr posiadał w tym okresie jakieś majątki również w Królestwie Polskim ${ }^{22}$.

Kolejne informacje odnoszące się do działalności Komorowskich pochodzą już z okresu po śmierci Władysława Warneńczyka. Zostają oni wspomniani w rozejmie, jaki zawarł Jan Jiskra z przedstawicielami administracji polskiej na pograniczu z Królestwem Węgier 30 listopada 1444 roku. W ramach tej umowy obydwie strony zobowiązały się powrócić do statusu sprzed wojny domowej, zwracając zdobyte na przeciwniku dobra, odpuścić na okres dwóch lat wymuszone na terenach przeciwnika hołdy oraz anulować poprzednie poro-

${ }^{18}$ F. Kiryk: Komorowski Piotr..., s. 427; G. Żabiński: Działalność w latach 1440-1457, s. 5.

${ }^{19}$ F. Uličný: Šlachtic Pongrác zo Svätého Mikuláša - najvýznamnejší slovenský vojak a politik v 15. Storočí. „Vojenská história: Časopis pre vojenskú históriu, múzejníctvo a archívnictvo“" 2017, č. 2, s. 69.

${ }^{20}$ J. Dąbrowski: Władysław I Jagiellończyk..., s. 45-46.

${ }^{21}$ P. Čaplovič: Oravský zámok. Martin 1967, s. 25; I. Floreková: Pol’ské vplyvy v dejinách Oravského panstva a hradu. „Zborník Oravského muzea“ 2010, č. 27, s. 34-48.

22 SPPP II, nr 3153-3154, s. 527-528; nr 3165, 3172, s. 530-531. 
zumienia między stronami. $\mathrm{Z}$ traktatu zostały jednak wyłączone umowy, jakie Jan Jiskra miał wcześniej zawrzeć z Komorowskimi. Rozejm ten stanowi też jedyny ślad obecności w źródłach Marcina Komorowskiego ${ }^{23}$. Treść umów Jiskry z Komorowskimi nie zachowała się, G. Żabiński przypuszcza, że dotyczyły one wypuszczenia Mikołaja Komorowskiego z niewoli, w której przebywał on od czasu swojego niefortunnego napadu na Preszów ${ }^{24}$.

Niezależnie od treści umów Komorowscy nie uszanowali rozejmu. Z lipca 1445 roku pochodzi list królowej Zofii do panów i komitatów tego obszaru, przedstawicieli obydwu stronnictw, będący odpowiedzią na skargi płynące na niezidentyfikowanego Komorowskiego, który jako przedstawiciel polskiej administracji dopuszczał się przestępstw na terenie Węgier. Królowa zapewniała, że strona polska podejmie starania o uspokojenie swojego urzędnika. W liście nie podano, o którego przedstawiciela tej rodziny chodzi, można jednak domniemywać, że list dotyczył Mikołaja - Piotr jako podżupan orawski był bowiem urzędnikiem węgierskim, niepodlegającym królowej, nie ma też żadnych przesłanek, by mógł to być wspominany wcześniej Marcin. Uwagę zwraca fakt, że informacje o rozbojach pojawiają się niecałe pół roku po domniemanym wypuszczeniu Mikołaja z niewoli ${ }^{25}$.

Po śmierci Władysława Jagiellończyka pod Warną sytuacja Królestwa Węgierskiego w dalszym ciągu była napięta. Władysław Pogrobowiec, który pozostał jedynym kandydatem do tronu Węgier, przebywał aż do przełomu 1452 i 1453 roku w Wiedniu, pozostając pod kuratelą swojego wuja Fryderyka Habsburga. Był to czas rywalizacji między obozami dawnych zwolenników Pogrobowca oraz stronnictwem pod wodzą Jana Hunyadyego, które skupiało dawnych zwolenników Jagiellończyka. Na terenie Górnych Węgier konflikt ten miał charakter starć między wojskami Jana Jiskry a sprzymierzeńcami Hunyadyego ${ }^{26}$.

Pomimo początkowego porozumienia Jan Hunyady nie akceptował konkurencji w walce o władzę i zaczął intrygować przeciwko Jiskrze. Prawdopodobnie to za jego namową wiosną roku 1446 na terytoria Jiskry napadli wspólnie Pangracz ze Svätého Mikuláša oraz Piotr Komorowski. Walki toczyły się głównie na obszarze komitatu liptowskiego, w ich czasie zaś obydwaj możni umocnili się na tym obszarze ${ }^{27}$. Sporna jest natomiast kwestia, jaką konkret-

${ }^{23}$ AGZ, T. 9, s. 59-63; dokument w polskim tłumaczeniu podaje S. Morawski: Sadecczyzna za Jagiellonów z miasty spiskiemi i księstwem oświęcimskiem. T. 2. Kraków 1865, s. 184-189 - biorąc pod uwagę przestarzały charakter publikacji, jakość tego tłumaczenia może budzić wątpliwości.

${ }^{24}$ G. Żabiński: Działalność w latach 1440-1457, s. 6.

${ }^{25}$ Dokumenty polskie z archiwów dawnego Królestwa Węgier. T. 1: (Do 1450 r.). Wyd. S. Sroka. Kraków 1998, nr 83, s. 111-112.

26 J. Špirko: Husiti, jiskrovci a bratríci..., s. 52-74.

${ }^{27}$ MNL OL, DF 213134; F. Uličný: Šlachtic Pongrác..., s. 70; F. Sasinek: Slovanski valečnici..., s. 34; G. Żabiński: Działalność w latach 1440-1457, s. 7. 
nie pozycję miał wtedy na Liptowie Piotr Komorowski. G. Żabiński twierdzi, za F. Kirykiem, że Piotr Komorowski już w okresie wcześniejszym posiadał tam znaczne wpływy, albowiem miał jakoby otrzymać od Władysława III Jagiellończyka godność tamtejszego żupana w roku $1444^{28}$. Nie ma jednak ku temu jasnych przesłanek źródłowych, co więcej — król Władysław III Jagiellończyk nadał w latach 1440-1441 zamki będące siedzibami tego komitatu (Likava, Liptovský Hrad i Liptovský Hrádok) panom z Kamenicy i Rozhanoviec (Rozgoňovci) ${ }^{29}$. Również według dawniejszych słowackich historyków Piotr Komorowski był w momencie wspólnego z Pangraczem ataku na Jiskrę żupanem Liptowa, jednak i te prace nie odnoszą się bezpośrednio do źródeł, w których Piotr występowałby z tym tytułem ${ }^{30}$. Pojawienie się Piotra Komorowskiego jako żupana Liptowa w roku 1446 należy połączyć ze wzmianką w kronice Bonfiniego o tym, że zajęcie przez Piotra stolicy liptowskiej stanowi typowy przykład bezprawia i anarchii, jakie dotknęły Górne Węgry w połowie $\mathrm{XV}$ wieku ${ }^{31}$. Wydaje się więc, że Piotr Komorowski nie posiadał żadnych praw do tytułu żupana liptowskiego. W roku 1446 podburzony przez Jana Hunyadyego przeciwko Janowi Jiskrze zdobył kilka twierdz na obszarze tego komitatu, w tym Likawę, która stała się jego stałą siedzibą na Węgrzech. Piotr Komorowski mógł uznać wtedy, że w związku z posiadaniem tych zamków i wykonywaniem de facto obowiązków żupańskich ma prawo do tego tytułu; sam zresztą tytułował się żupanem liptowskim dopiero w roku $1454^{32}$.

Konflikt między Janem Hunyadym a Janem Jiskrą narastał również w roku 1447. W marcu Hunyady zdołał nakłonić sejm węgierski do zniesienia funkcji siedmiu zarządców Węgier i ogłoszenia jego samego gubernatorem królestwa, co oddawało w jego ręce pełną kontrolę nad majątkami królewskimi ${ }^{33}$. Hunyadyemu udało się ponownie przekonać Pangracza i Piotra Komorowskiego do ataku na terytoria Jana Jiskry; tym razem zostali oni wsparci także przez brata Piotra - Mikołaja.

Celem napadów Pangracza i Komorowskich były bogate miasta górnicze położone w komitacie zwoleńskim, które zapewniały Jiskrze wysoki dochód. 27 kwietnia 1447 roku połączone wojska Pangracza i Komorowskich złupiły i podpaliły Kremnicę. Niedługo po tym podjęli oni próbę podobnego ataku na Bańską Bystrzycę, tam jednak ponieśli porażkę z rąk Jana Jiskry, a Piotr

${ }^{28}$ F. Kiryk: Komorowski Piotr..., s. 427; G. Żabiński: Działalność w latach 1440—1457, s. 7.

${ }^{29}$ D. Dvořáková: Stredoveké hrady na Slovensku: Život, kultúra, spoločnost'. Bratislava 2017, s. $336-337$.

${ }^{30}$ J. Kerekeš: Hrady Trenčianského Považia. „Letopis Matice Slovenskej“ 1867, roč. 3—4, zv. 1, s. 43-68; S. Hyroš: Zamok Lykava a jeho pani..., s. 87-89.

${ }^{31}$ Dekády uhorských dejín Antonia Bonfiniho. V: Pramene k dejinám Slovenska a Slovákov. 6: Pod osmanskou hrozbou. Ed. P. Dvořák. Bratislava 2005, s. 241.

${ }^{32}$ MNL OL, DL 15307; D. Dvořáková: Stredoveké hrady na Slovensku..., s. 332-334.

${ }_{33}$ M. Mišík: Husiti na Slovensku. Banská Bystrica 1928, s. 179-180. 
dostał się do niewoli. Mikołaj wraz z Pangraczem podjęli jeszcze w roku 1447 nieudane próby zbrojnego oswobodzenia Piotra ${ }^{34}$.

Sytuacja w Królestwie Węgierskim zmieniła się w październiku 1448 roku, kiedy to z powodu porażki Hunyadyego poniesionej z rąk Turków na Kosowym Polu została osłabiona jego pozycja w kraju. Z sytuacji tej skorzystał Jan Jiskra, by ustabilizować swoją obecność na obszarze Górnych Węgier. W maju roku 1449 zawarł traktat pokojowy z Pangraczem. W układzie tym Piotr i Mikołaj Komorowscy — razem z Balickimi — występują jako sojusznicy Jiskry, co oznacza, że musiał on jakoś nakłonić ich do przejścia na swoją stronę przed tą datą ${ }^{35}$.

Wspominana zmiana w relacjach Komorowskich z Jiskrą między 1447 a 1449 rokiem jest być może związana z potencjalnym konfliktem Piotra Komorowskiego z Pangraczem ze Svätého Mikuláša. Spór taki mógł dotyczyć wpływów w Liptowie, po roku 1449 Pangracz zaczął bowiem rościć sobie pretensje do tytułu żupana tej krainy ${ }^{36}$.

Komorowscy jednak nie pozostali długo sojusznikami Jana Jiskry, albowiem gdy ten podpisywał w roku 1452 traktat pokojowy z Hunyadym, obydwaj bracia zostali wymienieni jako stronnicy Hunyadyego ${ }^{37}$. G. Żabiński łączy to $\mathrm{z}$ dezercją $\mathrm{w}$ roku $1450 \mathrm{z}$ armii Jiskry jednego z jej dowódców, Piotra Aksamita, twierdząc, że Komorowscy mogli nawiązać z nim współpracę ${ }^{38}$.

W roku 1450 bardzo wzmocniła się pozycja Piotra Komorowskiego. Na Węgrzech zaczął on pełnić funkcję żupana orawskiego, otwarcie używając tego tytułu, co odbywało się za zgodą dotychczasowego żupana Mikołaja Balickiego, jednak było zupełnie niezgodne $\mathrm{z}$ prawem węgierskim ${ }^{39}$. Piotr zdołał też pozyskać dobra na obszarze należącego do Królestwa Polskiego Podhala. Dobra te prawdopodobnie zdobył drogą zastawu od ich właściciela Mikołaja Ratułda. Komorowski zyskał wtedy co najmniej sześć wiosek oraz zamek w Szaflarach, który miał dla niego strategiczne znaczenie ze względu na kontrolę drogi $\mathrm{z}$ jego węgierskich terytoriów do Królestwa Polskiego ${ }^{40}$.

Odwrotnie niż w wypadku Piotra, który zdołał wzmocnić swoją pozycję na Górnych Węgrzech w niespokojnych latach po śmierci Warneńczyka, sytuacja Mikołaja Komorowskiego została zachwiana, do czego przyczynił się

${ }^{34}$ J. Špirko: Husiti, jiskrovci a bratríci..., s. 62-63; G. Żabiński: Działalność w latach 1440-1457, s. 8-9.

${ }^{35}$ V. Chalupecki: Středověké listy ze Slovenska. Sbirka listů a listin, psaných jazykem národném. Praha 1937, č. 30, s. 32-34, G. Żabiński: Działalność w latach 1440—1457, s. 8-9.

36 F. Uličný: Šlachtic Pongrác..., s. 70-71.

37 J. Špirko: Husiti, jiskrovci a bratríci..., s. 74.

38 Tamże, s. 73-74; G. Żabiński: Działalność w latach 1440—1457, s. 12.

39 G. Żabiński: Działalność w latach 1440-1457, s. 15.

${ }^{40}$ J. Rafacz: Dzieje i ustrój Podhala Nowotarskiego za czasów dawnej Rzeczypospolitej Polskiej. Warszawa 1935, s. 42-44. 
konflikt z biskupem Oleśnickim. Z 15 sierpnia 1444 roku pochodzi zapiska sądu krakowskiego, informująca, że biskup krakowski wystąpił z polecenia króla Kazimierza Jagiellończyka przeciwko Janowi i Stanisławowi Masłomąckim, bezpośrednio dzierżącym Lubowlę i Podoliniec od Mikołaja Komorowskiego, mającym trzymać te zamki wbrew prawu i ze szkodą finansową biskupa sięgającą 12 tysięcy florenów ${ }^{41}$. Spór ten musiał zacząć się wcześniej, chociaż jeszcze w grudniu 1443 roku relacje między Komorowskimi a Oleśnickimi musiały być dobre, albowiem brat biskupa Jan ręczył w sądzie krakowskim za Piotrem Komorowskim we wzmiankowanym procesie ${ }^{42}$. Pogorszenie się stosunków między możnymi można powiązać ze wspomnianym listem królowej Zofii z lipca 1445 roku, w którym obiecywała ona powstrzymać rozboje Komorowskiego ${ }^{43}$; ewentualną przyczyną napięć mogło być również mianowanie przez Oleśnickiego innego faktora, Stanisława z Włostowic, w czerwcu 1444 roku, prawdopodobnie z powodu niewoli Mikołaja Komorowskiego ${ }^{44}$. Przypuszczalnie rozbójnicze działania prowadzone przez Mikołaja, być może mające na celu wspieranie walczącego o wpływy Piotra, były niewygodne dla biskupa krakowskiego, gdyż mogły prowadzić do zaognienia relacji z Węgrami. We wrześniu 1448 roku Oleśnicki napisał do króla Kazimierza Jagiellończyka oraz królowej Zofii dwa listy, w których informował o swoich problemach z Mikołajem Komorowskim. Z pism tych wynika, że biskup chciał odebrać Komorowskiemu zamki, ponieważ ów chciał je zastawić Węgrom. Oleśnicki informował także, że we wrześniu 1448 roku odbył się sąd polubowny, na którym stawił się Mikołaj Komorowski, sprawa jednak nie została wówczas rozstrzygnięta. Konflikt ten przeciągał się jeszcze w roku 1449 — Oleśnicki skarżył się wtedy na Komorowskiego Jiskrze oraz napisał do samego Mikołaja list z zażaleniami, nazywając go rozbójnikiem. Z korespondencji między biskupem Oleśnickim a Janem Długoszem z przełomu 1449 i 1450 roku wynika, że odpowiedzią Komorowskiego na listy biskupa było wysłanie swojego posła Piki z propozycją ustąpienia z Podolińca i Muszyny w zamian za spłatę długów Oleśnickich względem Mikołaja oraz umożliwienie mu bezpiecznego posiadania Lubowli ${ }^{45}$. W roku 1449 Mikołaj Komorowski zdołał opanować dla siebie leżący w komitacie szaryskim zamek Pławiec, z którego niepokoił miasto Bardejów ${ }^{46}$. Spór sądowy między Oleśnickim a Komorowskim musiał

${ }^{41}$ S. Gawęda: Możnowładztwo małopolskie w XIV $i$ w pierwszej połowie XV wieku. Kraków 1966, s. 122.

${ }^{42}$ SPPP II, nr 3153-3154, s. 527-528; nr 3165, 3172, s. 530-531.

${ }^{43}$ Dokumenty polskie z archiwów dawnego Królestwa Węier...

${ }^{44}$ J. Kurtyka: Polscy starostowie na Spiszu w XV i 1 połowie XVI w. „Acta Universitatis Nicolai Copernici. Historia” 1992, nr 26 (240), s. 206.

${ }^{45}$ CE, T. 1, nr 60, 61, 67, 68, 73, XCVI; G. Żabiński: Działalność w latach 1440-1457, s. 11 .

${ }^{46}$ CE, T. 1, cz. 2, nr 74, s. $78-79$. 
zakończyć się przed 13 lutego 1453 roku, gdyż wtedy po raz pierwszy jako zarządca Podolińca i Lubowli występuje Jan z Oleśnicy ${ }^{47}$.

Ważnym wydarzeniem, które wpłynęło także na losy Komorowskich, był powrót Władysława V Pogrobowca do Królestwa Węgierskiego. Związane to było z odbywającym się na przełomie 1452 i 1453 roku sejmem węgierskim w Bratysławie, którego cel stanowiło uporządkowanie spraw królestwa. Monarcha wydał wówczas dekret, który anulował wszystkie nadania matki i byłego jagiellońskiego konkurenta do tronu ${ }^{48}$. Najważniejszy skutek tego dekretu to odebranie Janowi Jiskrze wszelkich dóbr i dochodów, jakie dzierżył na Węgrzech; dodatkowo został on również pozbawiony swojego tytułu starosty Górnych Węgier. Jiskra przeszedł na służbę Fryderyka III, pozostając mimo wszystko w dobrych stosunkach z Pogrobowcem, o czym świadczy fakt, że był obecny na powtórnej koronacji młodego monarchy w październiku 1453 roku $^{49}$. Na sejmie podjęto też wiele decyzji korzystnych dla Hunyadyego został on obdarzony licznymi posiadłościami w Siedmiogrodzie i tytułem żupana bystrzyckiego, potwierdzono także jego tytuł gubernatora królestwa na czas małoletniości Pogrobowca, król zaś oficjalnie ogłosił amnestię dla tych, którzy walczyli przeciwko niemu w wojnie domowej50.

$\mathrm{Na}$ sejmie tym poruszono również sprawę braci Komorowskich i ich niepewnego sojusznika Pangracza ze Svätého Mikuláša, którzy zostali ogłoszeni rozbójnikami i skazani na banicję $e^{51}$. Zapis ten jednak pozostał martwą literą, a Pangracz wrócił do łask królewskich najpóźniej w lutym 1453 roku, wtedy otrzymał bowiem od króla potwierdzenie swoich zdobyczy z okresu anarchii po śmierci Władysława III Warneńczyka, w tym tytuł hrabiego Liptowa ${ }^{52}$. Także Komorowscy doszli do połowy roku 1453 do jakiejś formy ugody z władcą węgierskim i legalizacji swoich posiadłości w tym państwie, albowiem z czerwca tego roku pochodzi korespondencja, w której ich podwładni straszą w imieniu Piotra mieszczan bardejowskich sądem przed gubernatorem Janem Hunyadym $^{53}$, a dodatkowo sam Piotr występuje jako podwładny Jana Hunyadyego,

${ }^{47}$ J. Kurtyka: Polscy starostowie na Spiszu..., s. 202; G. Żabiński: Działalność w latach $1440-1457$, s. 9.

48 Decreta Regni Hungariae-Gesetze und verordnungen ungarns 1301-1457. Hrsg. F. Döry, G. Bonis, V. Bácskai. Budapest 1976, nr 375-383; J. Špirko: Husiti, jiskrovci a bratríci..., s. $74-78$.

49 J. Bartl: Vzt’ah Jána Jiskru a Jána Huňadyho. V: Husiti na Slovensku. Zborník príspevkov z konferencie. Zodp. red. I. Kaczarová. Lučenec 2001, s. 74-76; J. Úradník: Husiti a Jan Jiskra z Brandýsa vdejinách stredného Slovenska. Bakalárska diplomová práca, vedúci práce: P. Boček, 2014, s. 32.

${ }^{50}$ J. Špirko: Husiti, jiskrovci a bratríci..., s. 74-76.

${ }_{51}$ M. Mišík: Husiti..., s. 226.

${ }^{52}$ F. Uličný: Šlachtic Pongrác..., s. 62-83; J. Špirko: Husiti, jiskrovci a bratríci..., s. 76, przyp. 222.

53 J. Bartl: Vzt’ah Jána Jiskru..., s. 73. 
również z tytułem liptowskim ${ }^{54}$. Dziwić może tutaj fakt, że do obydwu możnych ze strony węgierskiej szły sygnały o możliwości zaakceptowania tytułu hrabiego liptowskiego - być może miało to na celu potencjalne ich skłócenie. Nie wiadomo dokładnie, dlaczego poniechano wyciągania konsekwencji względem Pangracza i Komorowskich, być może Hunyady od początku nie miał zamiaru realizować tego wyroku, który mógł być tylko grą polityczną obliczoną na uspokojenie poszkodowanych przez nich miast podlegających wcześniej Jiskrze. Hunyady oraz sam król Władysław V Pogrobowiec nie mieli zresztą interesu w pozbywaniu się potencjalnych sojuszników na północnych rubieżach kraju, cały czas trwała bowiem cicha walka między nimi o wpływy w państwie ${ }^{55}$.

Kwestią wymagającą pewnego omówienia jest spór, który toczył w latach 1453-1455 Jakub Tele z Paniowa, pełniący w roku 1453 funkcję kasztelana zamku Pławiec, z miastem Bardejów. Spór ten, znany dzięki trzem listom zachowanym w miejskim archiwum Bardejowa, dotyczył oskarżeń, jakie pod adresem Jakuba z Paniowa kierowali rajcy Bardejowa. Mieszczanie zarzucali Paniowskiemu zagrabienie mienia i w odwecie zaatakowali jego ludzi. Kasztelan pławecki jeszcze długo po straceniu swojej funkcji żądał od bardejowian zaprzestania pomówieńn ${ }^{56}$. G. Żabiński widzi w tej historii dowód na to, że Mikołaj Komorowski miał w roku 1453 dopuszczać się grabieży na mieszkańcach i dobrach Bardejowa ${ }^{57}$.

Wątpliwy jest jednak już sam fakt obecności w tym czasie Mikołaja na terenie Górnych Węgier. O ile w pismach pochodzących sprzed roku 1453, a dotyczących Pławca, jest mowa o Mikołaju Komorowskim, a działalność obydwu braci jest łatwa do odróżnienia w źródłach, o tyle w latach 1453-1455, ilekroć mowa jest w listach odnoszących się do spraw pławieckich o Komorowskim, pojawia się on bez imienia, tak jakby nagle przestano odczuwać potrzebę rozróżnienia braci ${ }^{58}$. Wspominanym Komorowskim jest raczej Piotr, to właśnie on pisał bowiem list do Bardejowa, już w roku 1455 jako właściciel Pławca ${ }^{59}$. Być może w momencie unormowania stosunków między Oleśnickimi a Komorowskimi i oddania przez Mikołaja Podolińca, Muszyny i Lubowli w ręce prawowitych dzierżawców Mikołaj przekazał bratu swoje węgierskie posiadłości i udał się do Polski, by zająć się posiadanymi tam włościami.

Skoro zatem to Piotr Komorowski został zwierzchnikiem Pławca, raczej wszelkie celowe działania wymierzone w Bardejów byłyby niezasadne, gdyż miasto było związane z Balickimi, którzy jeszcze w roku 1410 otrzymali na tym mieście zapis od cesarza Zygmunta pozwalający im pobierać 500 florenów

\footnotetext{
${ }^{54}$ G. Żabiński: Działalność w latach 1440-1457, s. 15.

${ }_{55}$ J. Bartl: Vzt’ah Jána Jiskru..., s. 73-75.

${ }^{56}$ V. Chalupecki: Středověké listy ze Slovenska..., nr 66, 68, 78.

57 G. Żabiński: Działalność w latach 1440-1457, s. 14.

58 V. Chalupecki: Středověké listy ze Slovenska..., č. 73, 74, s. 91-95.

59 Tamże, č. $94-95$, s. 82-83.
} 
rocznie $^{60}$. Jeśli więc ludzie Paniowskiego rzeczywiście dopuścili się kradzieży koni, to musiała to być albo samowola, albo zaniedbanie dyscypliny przez kapitana zamku. Natomiast możliwe jest, że faktycznie istniała odgórna zgoda na tolerowanie przez Pławiec oddziałów bratrzyków na swoich terenach, jednak do kontaktów tych Komorowski raczej się nie przyznawał - nie tylko ze względu na Bardejów, lecz także ogólną opinię na Węgrzech, zagrożoną przez wyrok sejmu w Bratysławie ze stycznia 1453 roku.

Na przełomie roku 1453 i 1454 ponownie zmieniła się sytuacja na terenie Górnych Węgier. Przeciwko bratrzykom została zorganizowana wyprawa dowodzona przez Mikołaja Újlakiego oraz syna Jana Hunyadyego, Władysława. Mimo klęski militarnej wyprawę zakończył układ z przywódcą bratrzyków Piotrem Aksamitem. Układ ten, choć korzystny dla Aksamita, gdyż przyznawał mu pewne osobiste korzyści na Węgrzech, pozwalając mu zachować niektóre zdobyte fortyfikacje, nie rozwiązywał w najmniejszym stopniu problemu dowodzonej przez niego grupy kilkunastu tysięcy rozbójników, którzy znaleźli się w podobnej sytuacji, co w momencie opuszczenia ich przez Jiskrę. Tym razem w rolę ich dowódcy wszedł sam Piotr Komorowski, występując na przełomie 1453 i 1454 roku z żądaniem wypłacenia sumy 11 tysięcy florenów, grożąc w przeciwnym razie otwartym buntem i atakiem na wojska królewskie wysłane do walki z bratrzykami ${ }^{61}$. Nie doczekawszy się odpowiedzi, żołnierze Piotra zaczęli żywić się i bogacić na własną rękę, nie oszczędzając przy tym klasztorów i kościołów oraz wchodząc we współpracę z Mikołajem Czajką Jaworskim, który również dołączył do akcji, a za którego czyny w następnym roku przepraszał Węgrów sam król Kazimierz IV Jagiellończyk ${ }^{62}$.

W roku 1454 doszło także do konfliktu między Piotrem Komorowskim a Pangraczem ze Svätého Mikuláša. W maju tego roku Pangracz został w dość niejasnych okolicznościach pochwycony przez Jana Hunyadyego. W czasie swojej niewoli zawarł z Hunyadym porozumienie podparte umową spisaną między stronami. W jej myśl Pangracz oficjalnie przyrzekł nie działać przeciwko królowi, co w praktyce oznaczało, że dołączył on do obozu Hunyadyego. Nagrodą dla Pangracza, poza odzyskaniem wolności, było potwierdzenie wszystkich pozyskanych przez niego w ubiegłych latach posiadłości, w tym i tytułu hrabiego liptowskiego. Umowa zezwalała mu również na prowadzenie działań wojennych przeciwko dwóm wrogom — jednemu z byłych oficerów Jana Jiskry, Marcinowi Valgacie oraz Piotrowi Komorowskiemu, którzy to zostali określeni jako niecni cudzoziemcy ${ }^{63}$.

${ }^{60}$ S.A. Sroka: Średniowieczny Bardiów i jego kontakty z Małopolska. Kraków 2010, s. $36-39$.

${ }^{61}$ M. Mišík: Husiti..., s. 239; J. Špirko: Husiti, jiskrovci a bratríci..., s. 89.

${ }^{62}$ J. Špirko: Husiti, jiskrovci a bratríci..., s. 90-91; G. Żabiński: Działalność w latach 1440-1457, s. 14.

${ }^{63}$ F. Uličný: Šlachtic Pongrác..., s. 72. 
Porażka stronnictwa Hunyadyego w kwestii uspokojenia sytuacji na Górnych Węgrzech musiała doprowadzić do osłabienia jego pozycji, albowiem już w lipcu 1454 roku król Władysław Pogrobowiec, współdziałając z Ulrykiem Cylejskim, zdołał nakłonić do powrotu Jana Jiskrę, z nadzieją, że ten będzie potrafił zapanować nad swoimi żołnierzami. Jiskra odzyskał kontrolę nad spiskimi, szaryskimi i zwoleńskimi miastami, jednakże jego pozycja nie była już tak silna jak wcześniej, dodatkowo musiał walczyć ze swoimi dawnymi podwładnymi ${ }^{64}$.

Dnia 14 listopada 1454 roku odbył się zjazd żup górnowęgierskich, dotkniętych działalnością podwładnych Piotra Komorowskiego. Na zjeździe tym podjęto decyzję o przeznaczeniu wysokich sum pieniężnych na rzecz zorganizowania wyprawy przeciwko Piotrowi Komorowskiemu oraz wybrano na jej wodza Oswalda Rozgonyiego. Mimo ponownego braku sukcesów militarnych w walkach przeciwko bratrzykom Jan Jiskra zdołał nakłonić na przełomie listopada i grudnia owego roku Piotra Komorowskiego i Oswalda Rozgonyiego do podjęcia rokowań pokojowych ${ }^{65}$.

Owocem tych prac był podpisany w Koszycach 24 grudnia 1454 roku traktat pokojowy między Piotrem a Oswaldem Rozgonyim. Umowa ta kończyła walki prowadzone między stronami, dodatkowo obligowała Piotra Komorowskiego do poddania Janowi Jiskrze, w zamian za odszkodowanie finansowe sięgające 15 tysięcy florenów, następujących fortyfikacji: położonych w gemerskiej żupie zamków Jelšava i Muran wraz z umocnionym obozem w Rožňavie, położonych w novohradzkiej żupie zamku Ozdín i fortyfikacji w Českom Brezove oraz położonego w żupie Abuja-Torna zamku Szádvár. Kwota odszkodowania miała być wypłacona w dwóch ratach ${ }^{66}$.

Spośród wymienionych $\mathrm{w}$ traktacie umocnień największe znaczenie miała Rožňava, znajdujący się na tamtejszym cmentarzu obóz stanowił bowiem zaplecze dla 2 tysięcy wojowników. Załogi pozostałych poddawanych przez Piotra twierdz liczyły po $150-300$ wojowników, tak więc rezygnacja z nich oznaczała pozbawienie się przez Piotra możliwości operacyjnych dla armii liczącej 3-4 tysiące ludzi na dość sporym obszarze ${ }^{67}$.

Umówione kwoty nie zostały jednak wypłacone, wobec czego podwładni Piotra ponownie przystąpili do akcji przeciwko reprezentantom władzy węgierskiej, a sam Komorowski przez cały rok 1455 i pierwszą połowę następnego lawirował, próbując z jednej strony zdobyć fundusze na utrzymanie swoich żołnierzy, a z drugiej zachować dobre stosunki z zagrożonym łupiestwem Bardejowem ${ }^{68}$.

${ }^{64}$ A. Gácsová: Boje Mateja I. proti Jánovi Jiskrovi z Brandýsa a bratrikom v rokoch 1458-1467. „Historický Časopis““ 1977, č. 25, s. 206.

${ }^{65}$ J. Špirko: Husiti, jiskrovci a bratríci..., s. 89-93.

${ }^{66}$ MNL OL, DL 15307; G. Żabiński: Dziatalność w latach 1440_1457, s. 15.

${ }^{67}$ P. Harčár: Bratrícke pevnôstky na východnom Slovensku. V: Husiti a bratríci na Slovensku..., s. 139-158.

${ }^{68}$ G. Żabiński: Działalność w latach $1440-1457$, s. 16-20. 
Lipiec roku 1456 przyniósł kolejny wstrząs dla Królestwa Węgierskiego, wtedy bowiem, wkrótce po bohaterskim obronieniu przed Turkami Belgradu, zmarł na dyzenterię Jan Hunyady. Wydarzenie to znów zwróciło przeciwko sobie ugrupowania możnych węgierskich. Na czele stronnictwa Hunyadych stanął przygotowywany do tej funkcji przez ojca Władysław Hunyady, który przejął również dowodzenie nad węgierskimi oddziałami znajdującymi się pod Belgradem oraz zdołał zabezpieczyć dla siebie i swojego brata Macieja Korwina (drugi syn Jana Hunyadyego nazywany jest tak ze względu na kruka - łac. corvus — jakiego Hunyady posiadali w herbie) spadek po ojcu. Do przejęcia przez Władysława Hunyadyego schedy po ojcu jako właściwym władcy państwa nie zamierzali jednak dopuścić Władysław Pogrobowiec oraz stojący u jego boku Ulryk Cylejski. W październiku 1456 roku monarcha zwołał sejm do Futagu (obecnie w północnej Serbii) na południu królestwa. Jednocześnie władca rozpoczął gromadzenie sił - oficjalnie, aby zorganizować krucjatę, jednakże równoległym celem tego przedsięwzięcia było poskromienie zapędów młodego Hunyadyego. Imiennie zostali tam zaproszeni jego znani przeciwnicy, w tym Jan Talafus oraz Jan Jiskra. Sam Władysław Hunyady również został przez króla zawezwany na sejm. Mimo początkowych oporów możny ostatecznie przyjechał do Futagu, gdzie oficjalnie pogodził się z królem i przysiągł na Ewangelię porzucić spory różniące go z Ulrykiem Cylejskim. Po sejmie armia krzyżowców udała się pod Belgrad z zamiarem zaatakowania Imperium Osmańskiego ${ }^{69}$.

Do twierdzy wpuszczony został jedynie mały orszak królewski, w którym obecny był także Ulryk Cylejski. Doszło więc do osobistego spotkania przywódców obydwu zwalczających się od lat obozów politycznych na Węgrzech. Sytuacja w twierdzy musiała być bardzo napięta, albowiem 9 listopada 1456 roku Władysław Hunyady zamordował swojego przeciwnika. Wykorzystując osamotnienie Władysława Pogrobowca, uwięził monarchę i wymusił na nim rozwiązanie stacjonujących pod Belgradem oddziałów, odwołanie pozostałych sił zmierzających w tym kierunku oraz przyrzeczenie niewyciągania względem siebie konsekwencji z powodu śmierci Ulryka. Na początku roku 1457 pewny siebie Władysław Hunyady wypuścił Pogrobowca, ten jednak zdołał po niedługim czasie wystąpić przeciwko Hunyadym. Obydwaj synowie Jana Hunyadyego zostali zaaresztowani w Budzie 14 kwietnia 1457 roku. Władysława stracono trzy dni później, jego brat Maciej został zaś uwięziony ${ }^{70}$.

O roli Piotra Komorowskiego we wspomnianych wydarzeniach informacji dostarcza list pisany przez Władysława Pogrobowca do mieszczan Bardejowa 9 grudnia 1456 roku, czyli w momencie, gdy monarcha był de facto więziony

${ }^{69}$ D. Papajík: Ladislav Pohrobek: (1440-1457): uherský a český král. České Budějovice 2016, s. 178-179; J. Špirko: Husiti, jiskrovci a bratríci..., s. 98.

${ }^{70}$ J. Bartl: Vzt’ah Jána Jiskru..., s. 74-76; D. Papajík: Ladislav Pohrobek..., s. 179-192; R. Urbanek: Konec Ladislava Pohrobka. Praha 1924, s. 64-96. 
przez Władysława Hunyadyego. Z listu wynika, że Piotr Komorowski był jednym z możnych wezwanych przez króla do Futagu, gdzie nie przybył osobiście ze względu na potrzebę zapewnienia bezpieczeństwa na podległych sobie terenach, miał natomiast wysłać do dyspozycji władcy kilka swoich oddziałów. W piśmie Piotr Komorowski występuje bez żadnego tytułu ${ }^{71}$.

Skoro Piotr Komorowski był wśród zawezwanych przez Władysława Pogrobowca do Futagu, król musiał w październiku 1456 roku dostrzegać także w nim potencjalnego sprzymierzeńca w walce o wpływy z Hunyadym. Niestawienie się osobiście Komorowskiego nie oznaczało również, że ten zrezygnował z politycznego sojuszu z monarchą, przeciwnie - oddanie na usługi królewskie paru własnych oddziałów musiało być dla Piotra poświęceniem w obliczu nieustannych walk, jakie toczył na terenie Górnych Węgier. Obraz taki potwierdza też korespondencja Bardejowa z Koszycami, z której wynika, że podwładni Komorowskiego byli jeszcze w grudniu 1456 roku nazywani ludźmi królewskimi, przed uwięzieniem władcy zaś prowadzona była wśród nich rekrutacja do wojska zmierzającego pod Belgrad ${ }^{72}$.

Fakt wystawienia takiego pisma przez monarchę w okresie, gdy był on na łasce Władysława Hunyadyego, mówi także o stosunku tego ostatniego do Piotra Komorowskiego - Hunyady zapewne cieszył się z nieobecności Komorowskiego oraz innych możnych Górnych Węgier u boku króla. $\mathrm{Z}$ podobnych względów władca był zmuszony odwołać $\mathrm{w}$ tym okresie również Jiskrę maszerującego $\mathrm{w}$ jego kierunku na czele swojej armii ${ }^{73}$. Pomimo wymowy listu, który tłumaczy Piotra przed mieszczanami Bardejowa z nieobecności na sejmie w Futagu, uwagę zwraca fakt niewymienienia w nim żadnego z tytułów, jakimi posługiwał się Komorowski w tamtym czasie. Zapewne zarówno Hunyady, jak i sam król liczyli na przychylną neutralność Komorowskiego, ale z niechęcią odnosili się do jego samozwańczych tytułów.

Egzekucja Władysława Hunyadyego po raz kolejny podzieliła możnych Królestwa Węgierskiego na wrogie sobie obozy. Tym razem na czele opozycji przeciwko królowi stanął Michał Szilágyi. Swoją pozycję zawdzięczał on więziom rodzinnym - był bratem wdowy po Janie, a matki Władysława i Macieja Hunyadych, Elżbiety, w imieniu której sprawował tymczasową władzę nad majątkiem tej rodziny. Po stronie króla stanęli odpowiedzialni za śmierć Hunyadyego Mikołaj Újlaki i Władysław Garai, zdołali oni również przeciągnąć na swoją stronę część możnych z zachodu kraju. Najważniejszym stronnikiem Pogrobowca pozostawał Jan Jiskra, który przebywał w tym czasie u boku

${ }^{71}$ P. Tóth-Szabó: A cseh-huszita mozgalmak és uralom története Magyarországon. Budapest 1917, s. 441.

${ }^{72}$ G. Żabiński: Działalność w latach 1440-1457, s. 22; J. Špirko: Husiti, jiskrovci a bratríci..., s. 99.

73 J. Úradník: Husiti..., s. 33. 
króla w Budzie, otrzymał także swój dawny tytuł kapitana Górnych Węgier. Pod koniec maja 1457 roku król wyjechał do Pragi w celu ożenku z francuską księżniczką Magdaleną. Wyjeżdżając, zabrał ze sobą Macieja Korwina, a pozostawił w Budzie Jana Jiskrę, de facto w charakterze zarządcy kraju. Wszystko to doprowadziło do otwartego wybuchu kolejnej już wojny domowej na Węgrzech pomiędzy zwalczającymi się frakcjami ${ }^{74}$.

Większość panów na Górnych Węgrzech poparła stronnictwo królewskie, a poza tym układem znalazł się Pangracz ze Svätého Mikuláša, który zdołał z kolei ułożyć się ze stronnictwem Siládich. Już 14 kwietnia 1457 roku zawarł on z Elżbietą Hunyady, wdową po Janie, ugodę, w myśl której wszelkie spory, jakie poróżniły go z Władysławem Hunyadym na przełomie 1456 i 1457 roku, w wyniku których stracił on część swoich posiadłości, zostały uznane za niebyłe. Pangracz otrzymał z powrotem swoje zamki oraz przysiągł popierać stronnictwo Michała Siládiego ${ }^{75}$. Takie położenie polityczne Pangracza musiało mieć wpływ również na Piotra Komorowskiego — zdecydowane opowiedzenie się jego rywala po stronie Siládich musiało jeszcze mocniej związać interesy ze stronnictwem królewskim, budowanym na terenach Górnych Węgier w głównej mierze przez jiskrowców. Widmo ponownej wojny domowej zostało jednak chwilowo odegnane już 8 września 1457 roku, wtedy to bowiem Jiskra zawarł w imieniu wszystkich swoich współpracowników traktat z Michałem Siládim odnoszący się do całości Górnych Węgier. Osobne wymienienie w nim Pangracza ze Svätého Mikuláša w kontekście zaprowadzenia pokoju na terenie komitatów Liptowa i Orawy sugeruje, że musiał on toczyć tam z jiskrowcami jakieś szczególne walki, czyli najpewniej kontynuował swój konflikt z Piotrem Komorowskim o Liptów ${ }^{76}$.

W okresie tym Piotr Komorowski przebywał na terenie Górnych Węgier, angażując się w konflikt lokalnych możnych o zamek w Kamenicy ${ }^{77}$. Spór ten jest o tyle istotny, że wyrok, jaki Piotr wraz z innymi możnymi pogranicza polsko-węgierskiego wydał w tej sprawie 27 kwietnia 1457 roku, obrazuje pozycję Komorowskiego. Wśród wystawców na pierwszym miejscu znajduje się właśnie Piotr Komorowski, który tytułuje się tam żupanem Liptowa i Orawy siedzącym na Likawie, a po nim są: Przecław z Dmosic jako starosta polskiego Spisza, Jan Talafus jako pan Rychnawy (przedstawiciel jiskrowców), bliżej nieokreślony Jan, siedzący na również bliżej nieokreślonym zamku Hungaricalo, Jan Wolski jako prokurator nowosądecki, kasztelan Muszyny oraz Klemens Wojcieszewski, kasztelan Lubowli ${ }^{78}$. Wyrok ten jest dowodem, że zarówno polska administracja Spisza, jak i siły wierne Janowi Jiskrze współdziałały

\footnotetext{
${ }^{74}$ R. Urbanek: Konec..., s. 96-102.

75 MNL OL, DF 94486; F. Uličný: Šlachtic Pongrác..., s. 72.

${ }^{76}$ M. Mišík: Husiti..., s. 254—255; J. Úradník: Husiti..., s. 33.

77 G. Żabiński: Działalność w latach 1440-1457, s. 21-23.

${ }^{78}$ MNL OL, DL 69015.
} 
z Piotrem Komorowskim w sprawowaniu władzy na obszarze Górnych Węgier oraz uznawały jego tytuły żupańskie.

Zaakceptowanie Piotra Komorowskiego jako rzeczywistego żupana liptowskiego, jak i życzliwa neutralność ze strony Hunyadyego w grudniu 1456 roku były zapewne związane z realnym wzmocnieniem się Komorowskiego w tym komitacie, wtedy bowiem jego konkurent do władzy tamże, Pangracz ze Svätého Mikuláša, popadł w konflikt z Władysławem Hunyadym. W toku tego konfliktu stracił na parę miesięcy zamki Branč, Strečno, Starhrad oraz miasto Żylina. Utrata tych dóbr musiała doprowadzić do jego osłabienia również w Liptowie ${ }^{79}$.

Kolejny wstrząs dla Węgier przyniosła niespodziewana śmierć Władysława Pogrobowca 23 grudnia 1457 roku w Pradze. Potężnie osłabiona została pozycja Jana Jiskry. Ze śmiercią młodego króla, o którego sprawę walczył przez 17 lat, stracił prawne i moralne podstawy do funkcjonowania w Królestwie Węgierskim ${ }^{80}$. Po śmierci Władysława Pogrobowca na nowo otwarta została kwestia tronu. W odbywającej się w lutym 1458 roku elekcji zwyciężył przebywający wtedy jeszcze w Pradze Maciej Korwin. Pokonał on dwóch kontrkandydatów, będących naturalnymi spadkobiercami Pogrobowca: męża jego siostry Elżbiety Rakuszanki, króla Polski Kazimierza Jagiellończyka oraz wuja zmarłego Habsburga, cesarza rzymskiego Fryderyka III, który w dodatku posiadał w dalszym ciągu Koronę Świętego Stefana. Swoje zwycięstwo nowy król zawdzięczał poparciu średniej szlachty, wynikającemu jeszcze z popularności jego ojca jako bohatera walk przeciw Turkom. Wobec małoletniości Korwina sytuacja taka oznaczała de facto rządy jego wuja Mikołaja Szilágyiego. Jiskra, mimo że początkowo uznał nowego monarchę, już w marcu 1458 roku, będąc na dworze polskiego króla Kazimierza Jagiellończyka, próbował nakłonić go do walki o koronę Węgier. Sam Kazimierz najprawdopodobniej nie był zbytnio zainteresowany taką ofertą, jednak nie odrzucił jej całkowicie, albowiem Jiskra jeszcze w połowie 1458 roku wezwał miasta Górnych Ziem Królestwa Węgierskiego: Bardejów, Preszów, Lewoczę i Koszyce, do posłuszeństwa polskiemu królowi, obiecując, że ten będzie ich bronić polskimi wojskami. Takie zachowanie Jana Jiskry doprowadziło do wznowienia walk na terenie Górnych Węgier. W miejsce Jiskry na ich starostę Korwin wyznaczył Sebastiana Rozgonyiego, który już w kwietniu 1458 roku zaatakował pozostałych na Węgrzech stronników Jiskry ${ }^{81}$.

\footnotetext{
79 MNL OL, DF 94486; F. Uličný: Šlachtic Pongrác..., s. 72.

${ }^{80}$ V. Chalupecki: Středověké listy ze Slovenska..., č. 102, s. 90-91; A. Gáscová: Boje Mateja I..., s. 189-191.

${ }^{81}$ F. Oslanský: Portrét Jána Jiskru z Brandýsa. V: Husiti na Slovensku: Zborník referátov z konferencie pri príleţitosti 550. výročia bitky pri Lučenci. Ed. I. Kaczarová. Lučenec 2011, s. 84; R. Urbanek: Konec..., s. 110.
} 
Pierwszym celem prowadzonej przez Rozgonyiego ofensywy był zamek Vadna, którego bronił niewymieniony w źródłach z imienia Komorowski oraz kapitan wojsk jiskrowców Marcin Valagata. Dowódcy ci mieli do dyspozycji ok. 700 ludzi przeciwko przeważającym siłom nieprzyjaciela, które w znacznej mierze składały się z żądnych krwi chłopów. Zmuszeni do wycofania się, zostali doścignięci i pokonani przez atakujących. Po bitwie miało dojść do rzezi jeńców, oszczędzić miano jedynie obydwu dowódców ${ }^{82}$.

$\mathrm{O}$ ile sam przebieg starcia nie jest raczej kwestionowany $\mathrm{w}$ historiografii, o tyle nie ma zgodności odnośnie do tego, który z braci był tam obecny. W starszej słowackiej literaturze przedmiotu pisano za źródłami po prostu o Komorowskim - Alžbeta Gácsová ${ }^{83}$ widziała tam Piotra, G. Żabiński zaś twierdził, opierając się na tekście Długosza, że obecny tam był Mikołaj Komorowski ${ }^{84}$. Za tezą słowackiej badaczki przemawia to, że Mikołaj nie był już od kilku lat widoczny w innych źródłach powstałych w tym rejonie. Dodatkowo użycie przez Macieja Korwina w dokumencie dla Rozgonyiego z września 1458 roku samego nazwiska Komorowski również zdaje się wskazywać na Piotra, albowiem w źródłach węgierskich, gdy nazwisko to pojawia się bez podanego imienia, zwykle odnosi się właśnie do niego ${ }^{85}$.

Ofensywa Rozgonyiego po zdobyciu Vadny nabrała rozpędu. Dnia 21 maja w bitwie pod Szaryskim Potokiem rozgromił on wojska bratrzyków prowadzone przez Talafusa i Aksamita. Drugi z tych dowódców poległ w czasie tego starcia, Talafus natomiast wycofał się z garstką swoich żołnierzy do Szaryskiego Zamku. Dopiero potężne mury tej fortecy zastopowały uderzenie wojsk królewskich. Maciej Korwin zdecydował się podpisać porozumienie z jiskrowcami 29 września 1458 roku. W myśl tej umowy uwolniony został wzięty pod Vadną Marcin Valagata, a prawdopodobnie również Piotr Komorowski ${ }^{86}$.

Śmierć Piotra Aksamita ponownie otwierała sprawę zamku Pławiec położonego koło Bardejowa, chociaż istnieje przesłanka, że wrócił on już przed tym zdarzeniem w ręce Komorowskiego. Z listu Mikołaja Balickiego z 28 kwietnia 1458 roku do miasta Bardejowa wynika, że kasztelanem tego zamku był wtedy ponownie Klemens z Wojcieszyc ${ }^{87}$. G. Żabiński wysuwa jednak przypuszczenie, że Klemens mógł być w tym czasie podwładnym Jana Jiskry, we wspomnianym piśmie Balicki obiecywał bowiem miastu interweniować właśnie u Czecha w sprawie kontaktu z Klemensem, jednak, jak zauważa sam badacz, nie jest tam wprost wyrażone, że Klemens

82 J. Špirko: Husiti, jiskrovci a bratríci..., s. 103; MNL OL, DL 15279.

${ }^{83}$ A. Gáscová: Boje Mateja I..., s. 191-192.

${ }^{84}$ G. Żabiński: Działalność w okresie rządów Korwina, s. 80.

${ }^{85}$ MNL OL, DL 15279.

86 A. Gáscová: Boje Mateja I..., s. 192-194; J. Špirko: Husiti, jiskrovci a bratríci..., s. $105-107$.

${ }^{87}$ MNL OL, DF 213704. 
podlegał Jiskrze, zamek zaś był w roku $1460 \mathrm{z}$ powrotem w rękach Piotra Komorowskiego ${ }^{88}$.

Na przełomie 1458 i 1459 roku Piotr Komorowski znajdował się w Liptowie, gdzie stosunkowo spokojnie pełnił obowiązki żupana tego rejonu. Pisał o tym 29 marca mieszkańcom Kremnicy ${ }^{89}$. W czerwcu 1459 roku Piotr Komorowski, tytułując się żupanem i sędzią liptowskim, wydał wyrok dotyczący dziedziczenia dóbr dla rodziny Fejérpataki (Belopotockovcov) ${ }^{90}$. Sprawą tej familii zajmował się jeszcze w roku następnym ${ }^{91}$. W 2. poł. 1459 roku umarł Mikołaj Balicki, a po jego śmierci Piotr Komorowski otrzymał potwierdzenie nadań, jakie ten mu uczynił, zapewne więc wzmocniła się, chociażby pod względem prawnym, jego pozycja na obszarze Orawy ${ }^{92}$.

W roku 1460 zachodnia część pogranicza polsko-węgierskiego, w tym dzierżone przez Piotra Komorowskiego tereny Podhala, była zagrożona działalnością rozbójniczą Włodka Młodszego ze Skrzynna ${ }^{93}$. Polską reakcją na te napady była wyprawa wojenna zorganizowana przez ówczesnego podkomorzego i starostę krakowskiego Mikołaja Pieniążka, którą wsparł swoimi siłami również Piotr Komorowski. Połączone wojska zdołały po krótkim oblężeniu opanować 3 kwietnia 1460 roku zamek w Barwałdzie. Na początku maja zdobyły natomiast położony nieopodal Żywca zamek na górze Grójec $^{94}$.

Po sukcesach odniesionych w roku 1459 starosta Górnych Węgier Stefan Zápolya kontynuował na początku roku 1460 swoją walkę przeciwko siłom wiernym Janowi Jiskrze i Komorowskiemu, wypychając ich prawie całkowicie z terenów Spisza i Szarysu. Szaryski Hrad, dawniej główna siedziba Jiskry, został oblężony, w stanie zagrożenia zaś postawiony został podlegający Komorowskim zamek Pławiec ${ }^{95}$. W połowie roku kasztelan Pławca Kunath czynił przygotowania do obrony twierdzy, o których informował mieszkańców Bardejowa, słusznie uznając, że utrzymanie się na zamku może zależeć od dobrych relacji z tym miastem, szczegól-

${ }^{88}$ G. Żabiński: Działalność w okresie rzadów Korwina, s. 81.

${ }^{89}$ MNL OL, DF 250009; G. Żabiński (Działalność w okresie rząów Korwina, s. 82) podaje błędny numer fotokopii dokumentu.

${ }^{90}$ MNL OL, DL 64882.

${ }^{91}$ MNL OL, DL 64883.

${ }_{92}$ F. Sikora: Mikołaj Ossoliński h. Topór. W: PSB, T. 24, s. 424-425.

${ }^{93}$ S.A. Sroka: Skrzyński Włodek. W: PSB, T. 38, s. 472-473; B. Czwojdrak: Dziersław z Rytwian - rzekomy husyta polski. „Teki Krakowskie” 1999, T. 10, s. 7; J. Marszałek: Katalog grodzisk i zamków w Karpatach. Warszawa 1993, s. 266.

${ }_{94}$ Annales, lib. 12, s. 411-412; F. Sikora: Mikołaj Pieniążek z Witkowic herbu Jelita. W: PSB, T. 26, s. 102-104.

95 A. Gáscová: Boje Mateja I..., s. 200-201; J. Jurok: Čeští husitští a katoličtí kondotiéri z Moravy na Slovensku v 15. století (obdobi bratř́kư). „Vojenská história“ 2005, č. 4, s. $7-8$. 
nie że o wsparcie ze strony mieszczan zabiegała także druga strona konfliktu $^{96}$.

Jan Jiskra próbował jeszcze wtedy przez jakiś czas spiskować przeciwko Korwinowi - najpierw na Wawelu, potem zaś u Fryderyka III. Polski monarcha był jednak niechętny angażowaniu się w sprawy Węgier, Fryderyk III z kolei został zbrojnie pokonany przez Korwina. Ostatecznie traktat pokojowy między monarchami zawarto $\mathrm{w}$ kwietniu 1462 roku, jednym $\mathrm{z}$ jego warunków była wypłata przez Korwina godziwego odszkodowania dla Jana Jiskry. Ten z kolei na przełomie kwietnia i maja roku 1462 wydał Maciejowi wszystkie zamki, jakie zajmowali wierni mu ludzie na terenie Węgier, w zamian za co został przyjęty na służbę i otrzymał znaczne posiadłości oraz godności na południowo-wschodnich krańcach królestwa. Do swojej śmierci, która nastąpiła przed 9 lutego 1471 roku, z sukcesami i wiernie służył Korwinowi jako dowódca wojskowy w jego walkach z Mołdawią i Turkami, nie mieszając się już więcej do spraw Górnych Węgier ${ }^{97}$.

Pozostający dotychczas w rękach Komorowskiego zamek Pławiec był już na początku kwietnia 1462 roku opanowany przez Stefana Zápolyę ${ }^{98}$, nie ma jednak jasności, w jakich okolicznościach do tego doszło. Piotr Komorowski był wtedy już bowiem postrzegany przez Zápolyę jako sojusznik w walce przeciwko bandom rozbójników, zarówno w działaniach zbrojnych, jak i podczas stabilizowania sytuacji poprzez przyjmowanie ich band na swój żołd ${ }^{99}$. Informacji o przejściu Piotra na służbę Macieja Korwina dostarcza list prymasa Węgier Dionizego Szecseiego do tego monarchy z 8 maja 1462 roku. Z treści pisma wynika, że Piotr był już wtedy od dłuższego czasu na służbie władcy, a arcybiskup informował króla o spotkaniu, jakie odbył z Komorowskim oraz palatynem Michałem Orszakiem w celu uspokojenia sytuacji na podległych Piotrowi terytoriach. W liście znajdują się informacje o tym, że Komorowski skarżył się na nieprzestrzeganie przez stronę węgierską zobowiązań finansowych względem niego, przez co miał trudności z utrzymaniem dyscypliny wśród swoich żołnierzy i powstrzymywaniem ich od rozbojów. Aby rozwiązać tę sytuację, prymas wraz z palatynem zdecydowali o przydzieleniu mu rocznego dochodu z dziesięciny na obszarze czterech komitatów: liptowskiego, orawskiego, turczańskiego i zwoleńskiego, który miał wynieść przeszło 2 tysiące florenów. Prymas donosił także monarsze o zatargach między Komorowskim a bliżej nieokreślonymi przedstawicielami królestwa ${ }^{100}$. Możliwe

${ }^{96}$ MNL OL, DF 214073; A. Gáscová: Boje Mateja I..., s. 201; G. Żabiński: Działalność w okresie rząów Korwina, s. 82.

${ }^{97}$ MNL OL, DL 15279; F. Oslanský: Portrét Jána Jiskru..., s. 61—62.

${ }^{98}$ G. Żabiński: Działalność w okresie rzadów Korwina, s. 82.

99 A. Gáscová: Boje Mateja I..., s. 204-205.

100 Tamże, s. 206-207; J. Špirko: Husiti, jiskrovci a bratríci..., s. 113; G. Żabiński: Dziatalność w okresie rząów Korwina, s. 83. 
więc, że wspomniany przez arcybiskupa spór dotyczył zajęcia zamku pławieckiego przez ludzi Stefana Zápolyi. O rozwoju tego konfliktu w następnych tygodniach informuje również list Macieja Korwina do Piotra Komorowskiego z 3 lipca 1462 roku. List ten był reakcją na wysyłane do króla przez górnowęgierską szlachtę skargi odnoszące się do nielegalnego zagarnięcia przez Komorowskiego ich posiadłości i dochodów. Wydaje się zatem, że doszło do sytuacji podobnej jak w roku 1455 - Piotr ze względu na nieprzychylność starosty Górnych Węgier nie mógł liczyć na terminowe wypłacanie należności, jakie dłużne mu było królestwo, i był zmuszony szukać pieniędzy na własną rękę, ograbiając stronników nieprzychylnego mu urzędnika. W piśmie tym Maciej Korwin nazywał Komorowskiego swoim wiernym poddanym, tytułując go żupanem Liptowa, Orawy, Zwolenia i komitatu turczańskiego ${ }^{101}$. Nie jest znany dokument formalnego nadania tych godności Piotrowi, być może więc król akceptował po prostu w liście stan faktyczny, licząc się z silną pozycją Komorowskiego na tych obszarach. O ile Liptow i Orawa były we władaniu polskiego możnego od dłuższego czasu, o tyle dziwić mogą pozostałe tytuły Komorowskiego wymienione przez monarchę. Żupa turczańska należała $\mathrm{w}$ tym okresie do Balickich ${ }^{102}$, chociaż Piotr Komorowski wzmocnił wówczas swoją pozycję w tym rejonie, po prostu przejmując na swój żołd załogi kilku tamtejszych zbójnickich zamków ${ }^{103}$. Możliwe jest, że król Maciej, nazywając Piotra Komorowskiego żupanem w tym komitacie, próbował poróżnić go z Balickimi, jednak bezskutecznie, ponieważ sam Piotr tego tytułu nie używał ${ }^{104}$. Silną pozycję w żupie zwoleńskiej musiał Komorowski uzyskać w kwietniu 1462 roku po przejęciu dowodzenia nad byłymi siłami Jiskry w tym rejonie, chociaż tytułu żupana zwoleńskiego również nie używał ${ }^{105}$.

We wrześniu i październiku 1462 roku Piotr Komorowski był obecny w Polsce, gdzie wraz z Przecławem z Dmoszyc wspomagał Mikołaja Pieniążka w walkach przeciwko Włodkowi Młodszemu ze Skrzynna. Starcia te skończyły się całkowitym zwycięstwem Pieniążka ${ }^{106}$.

W latach 1463-1465 Piotr Komorowski prowadził działania wojenne skierowane przeciwko królowi i Zápolyi, ze zmienną częstotliwością, cały czas próbując negocjować ze starostą Górnych Węgier spłatę swoich pretensji finansowych ${ }^{107}$. W tym czasie blisko współpracował z Przecławem z Dmoszyc

${ }_{101}$ MNL OL, DL 30851; G. Żabiński: Działalność w okresie rząów Korwina, s. 83.

102 MNL OL, DF 214253, 214339.

103 A. Gáscová: Boje Mateja I..., s. 205.

${ }^{104}$ G. Żabiński: Działalność w okresie rzadów Korwina, s. 86.

105 A. Gáscová: Boje Mateja I..., s. 204-205: G. Żabiński: Działalność w okresie rząów Korwina, s. 86.

106 G. Żabiński: Działalność w okresie rządów Korwina, s. 82.

107 P. Tóth-Szabó: A cseh-huszita..., s. 87; G. Żabiński: Działalność w okresie rządów Korwina, s. 83. 
oraz innymi przywódcami bratrzyków, takimi jak Jan Talafus z Ostrowa czy dawny podwładny Piotra - Jakub Tele z Paniowa ${ }^{108}$. Pod koniec 1465 roku Piotr Komorowski wraz ze starostą Przecławem z Dmoszyc zakończyli swój spór ze Stefanem Zápolyą. W styczniu 1466 roku odbył się zjazd, w czasie którego krewny Stefana - Emeryk, naradzał się z nimi oraz innymi panami Górnych Węgier na temat przywrócenia porządku. W roku 1467 Piotr Komorowski występował już jako sojusznik Zápolyi. Zapewne w roku następnym uregulował także swoje stosunki z monarchą ${ }^{109}$. Do roku 1467 trwały jeszcze walki między węgierskimi wojskami królewskimi a bratrzykami, którzy zostali ostatecznie pokonani przez Korwina w bitwie pod Vel'kými Kostol'anami na przełomie 1466 i 1467 roku.

Między 1466 rokiem a majem 1469 roku zmarł dawny konkurent Piotra Komorowskiego Pangracz ze Svätého Mikuláša. Jego spadkobiercy próbowali wtedy odzyskać na drodze sądowej zamki liptowskie, starania te jednak nie odniosły skutku ${ }^{110}$. Piotr pozyskał wtedy również zamek Stary Hrad w komitacie turczańskim, należący dawniej do Pangracza. Wszystko to świadczy o przychylności Macieja Korwina, jaką cieszył się Komorowski w tym okresie. Przychylność ta najpewniej wynikała ze wznowienia rywalizacji między Korwinem a Jagiellonami, tereny Piotra jako położone po obydwu stronach granicy polsko-węgierskiej miały bowiem wielkie znaczenie strategiczne w potencjalnym konflikcie wojskowym między Polską a Węgrami ${ }^{111}$.

Król Polski Kazimierz Jagiellończyk już wcześniej rozpoczął zabiegi o pozyskanie względów Komorowskiego. W roku 1467 nadał mu w dziedziczne posiadanie Żywiecczyznę $e^{112}$. Tak potężna pozycja Piotra Komorowskiego jako posiadacza znacznych terenów po obydwu stronach Tatr nie trwała jednak długo, nie było bowiem możliwe utrzymanie dobrych relacji z obydwoma królestwami wobec ich jawnej rywalizacji. Gdy w roku 1471 doszło do niesławnej wyprawy św. Kazimierza na Węgry, Piotr Komorowski włączył się aktywnie w działania po stronie polskiego królewicza. Już w sierpniu 1471 roku przygotował oddziały zbrojne mające wesprzeć św. Kazimierza, po jego porażce zaś udzielił mu schronienia w swoich węgierskich warowniach ${ }^{113}$. Reakcją Macieja

${ }^{108}$ K. Baczkowski: Przectaw z Dmosic (Dmoszyc) h. Ostoja. W: PSB, T. 28, s. 678-680; G. Żabiński: Działalność w okresie rząów Korwina, s. 84-86.

${ }^{109}$ G. Żabiński: Działalność w okresie rzadów Korwina, s. 85.

110 D. Dvořáková: Stredoveké hrady na Slovensku..., s. 332-334, 336-368; F. Uličný: Šlachtic Pongrác..., s. 75-81.

111 M. Mišík: Husiti..., s. 315; G. Żabiński: Działalność w okresie rzadów Korwina, s. $86-87$.

112 Z. Rączka: Archiwalia żywieckie w Archives nationales w Paryżu. „Karta Groni” 1991, nr 16, s. 196-201; Taż: Żywiec. Rys historyczny od powstania miasta do 1918 roku. Żywiec 1997, s. $16-17$.

113 Annales, lib. 12, s. 284; Rozbiór krytyczny Annalium..., s. 288; M. Plewczyński: Wojny Jagiellonów z wschodnimi i południowymi sqasiadami Królestwa Polskie- 
Korwina na poparcie udzielone Jagiellończykowi przez Komorowskiego był atak na dzierżone przez niego zamki na terenie Węgier, do którego doszło po zawarciu pokoju z Kazimierzem Jagiellończykiem. Długosz podaje, że Piotr Komorowski rozkazał poddać bez walki większość swoich twierdz, decydując się stawiać opór jedynie na zamkach Likawie i Orawie. Kronikarz pisze również, że w zamku Orawie Piotr przebywał ze swoją żoną, co stanowi jedyną, poza faktem posiadania legalnego potomstwa, informację o małżonce Komorowskiego. Ostatecznie Piotr poddał Korwinowi obydwa pozostałe zamki za cenę możliwości odejścia wraz z dobytkiem oraz 8 tysięcy florenów odszkodowania ${ }^{114}$.

W roku 1476 stosunki między Polską a Węgrami po raz kolejny uległy pogorszeniu, tym razem za sprawą działań krzyżackich. Przedstawiciele zakonu starali się wtedy podburzyć Macieja Korwina przeciwko Polsce, by zyskać w nim sojusznika w walce o wyswobodzenie się spod jej wpływów. Według relacji Długosza król węgierski próbował w tym czasie ponownie pozyskać dla siebie Piotra Komorowskiego, oferując mu jego dawne zamki na Węgrzech w zamian za wydanie Żywca, Szaflar i Barwałdu. Kronikarz odnotowuje również, że krążyły ówcześnie plotki odnośnie do tego, że Piotr Komorowski miał zamiar przyjąć ofertę.

Dalszy przebieg wydarzeń jest dość zagadkowy, albowiem według Długosza już w roku 1477 Żywcem rozporządzał nie Piotr a Mikołaj Komorowski, który otwarcie kolaborował z Maciejem Korwinem. Kazimierz posyłał do niego posłów, by ci przemówili mu do rozsądku. Mikołaj miał jednak wszystkie te propozycje odrzucić i dalej spiskować z węgierskim monarchą. Ostatecznie Jakub z Dębna, ówczesny wojewoda sandomierski i starosta krakowski, z polecenia króla obległ i zdobył posiadłości Komorowskiego. Sam Mikołaj miał uciec i po niedługim czasie odzyskać, dzięki wpływowym przyjaciołom w radzie królestwa, łaskę Kazimierza Jagiellończyka, który przyjął go na audiencję. Chcąc otrzymać to, co stracił, odrzucił królewską propozycję nadania dóbr koła Chełma i udał się do Macieja Korwina, licząc na jego wstawiennictwo. Ze strony węgierskiego monarchy spotkały go jednak jedynie kpiny, tak więc upokorzony wrócił przed oblicze Kazimierza Jagiellończyka i otrzymał od niego dobra w Krasnymstawie, gdzie po niedługim czasie w niesławie zmarr ${ }^{115}$.

Przedstawiony przez Długosza przebieg wydarzeń na Żywiecczyźnie znajduje potwierdzenie $\mathrm{w}$ badaniach archeologicznych — opisane przez niego zniszczenia rzeczywiście miały wtedy miejsce ${ }^{116}$. Również przekaz o dalszych

go w XV wieku. Siedlce 2005, s. 107; G. Żabiński: Działalność w okresie rzadów Korwina, s. 89.

114 Annales, lib. 12, s. 329-330.

115 Tamże, s. 394-395.

116 P. Dyrlaga: Co wiemy o dziejach Starego Żywca w XV-XVI wieku? „Gronie” 2013, nr 13, s. 41-46; Rozbiór krytyczny Annalium..., s. 351. 
losach Mikołaja Komorowskiego wydaje się wiarygodny, z tym że zmarł on dopiero ok. 1486 roku $^{117}$. Niejasne natomiast są okoliczności, w jakich Mikołaj doszedł do władzy w Żywcu. W starszej literaturze przyjmowano, że Piotr wraz z synem Aleksandrem zmarli w roku 1476, Mikołaj zaś objął Żywiec we władanie w imieniu Jana, małoletniego syna Piotra ${ }^{118}$. Badania G. Żabińskiego oraz Stanisława A. Sroki obaliły jednak taką tezę, Piotr żył bowiem jeszcze 20 kwietnia 1480 roku i przebywał wtedy na Węgrzech, dzierżąc zamek Blatnica, gdzie zmarł przed 1484 rokiem, a dodatkowo cały czas był tytułowany panem ziemi żywieckiej ${ }^{119}$. G. Żabiński tłumaczy narrację Długosza, wysuwając hipotezę, że Piotr Komorowski przybył zawezwany przez Macieja Korwina i został przez niego uwięziony, gdyż ten mu nie ufał. Trzymając więc Piotra, Maciej Korwin łatwo porozumiał się z Mikołajem, który pod nieobecność brata dysponował jego majątkiem. Po wszystkim zaś nadał Piotrowi zamek Blatnica jako odszkodowanie za utratę Żywca ${ }^{120}$. Teza ta wydaje się słuszna - brak pełnej dobrowolności Komorowskich w ich kontaktach z Korwinem tłumaczyłaby łagodność, z jaką Mikołaj został potraktowany przez króla po swoim buncie, oraz fakt, że syn Piotra Jan już w roku 1484 odzyskał większość z dziedzictwa po swoim ojcu ${ }^{121}$. Dobra blatnickie Piotr Komorowski otrzymał jednak nie od króla Macieja jako odszkodowanie, ale drogą zastawu od Stefana Pangracza, brata swojego dawnego rywala Pangracza ze Svätého Mikuláša, i to dopiero w roku $1479^{122}$. W ostatnich latach swojego życia Piotr Komorowski zawarł przymierze z rodziną Pangracza, aranżując małżeństwo swojego syna Jana, zapewne jedynego, który przeżył ojca, z córką Stefana Zofią. Małżeństwo to zostało zawarte jednak już po śmierci Piotra w roku 1484, co pokazuje, że jego syn kontynuował politykę ojca względem tej rodziny ${ }^{123}$.

$\mathrm{Na}$ zakończenie warto wspomnieć jeszcze o potencjalnym wizerunku tego możnego. Na ołtarzu znajdującym się pierwotnie w kościele w Liptowskiej Marze przedstawiono scenę sądu Poncjusza Piłata nad Jezusem. Zdaniem Soni Kovačevičovej Piłat został tam ucharakteryzowany na żupana liptowskiego. Biorąc pod uwagę, że obraz ten powstał ok. połowy XV wieku, jest możliwe, że wzorem dla malarza był właśnie Piotr Komorowski jako rzeczywisty administrator tych terenów. Piłat, a więc potencjalnie Piotr Komorowski, został

117 G. Żabiński: Działalność w okresie rządów Korwina, s. 90.

118 F. Kiryk: Komorowski Piotr..., s. 427-429; Z. Rączka: Żywiec. Rys historyczny..., S. 21 oraz przyp. 59.

119 S.A. Sroka: Komorowscy z Żywca..., s. 46-47; G. Żabiński: Działalność w okresie rząów Korwina, s. 90.

${ }^{120}$ G. Żabiński: Działalność w okresie rząów Korwina, s. 90.

121 F. Sikora: Mszański zespół osadniczy w średniowieczu. W: Ojczyzna bliższa i dalsza. Studia historyczne ofiarowane Feliksowi Kirykowi w sześćdziesiata rocznicę urodzin. Red. J. Chrobaczyński, A. Jureczko, M. Śliwa. Kraków 1993, s. 134-146.

${ }_{122}$ D. Dvořáková: Stredoveké hrady na Slovensku..., s. 255-256.

${ }^{123}$ S.A. Sroka: Komorowscy z Żywca..., s. 47. 
na tym ołtarzu przedstawiony jako wysoki i szczupły brunet o ostrych rysach twarzy, ubrany w strój węgierskiego żupana ${ }^{124}$.

Podsumowując zaprezentowane w niniejszym artykule rozważania, można stwierdzić, że parę kwestii zostało zweryfikowanych. Odrzucić należy przyjmowane wcześniej wiadomości o imieniu ojca i dziadka Komorowskich oraz o ich bratankach jako niepotwierdzone źródłowo. Podobnie ma się sprawa z potencjalną obecnością Piotra w Serbii w 1437 roku. Weryfikacji poddana została również opinia polskich historyków na temat przyczyn pozyskania przez Piotra tytułów i majątków na Węgrzech, które zawdzięczał raczej własnej samowoli i protekcji Balickich niż łasce Władysława III Jagiellończyka. Nowymi wątkami wprowadzonymi do tematu są kwestia połączenia Piotra z wizerunkiem Piłata na ołtarzu pochodzącym z kościoła w Liptowskiej Marze oraz oszacowanie sił, jakimi Piotr dysponował w szczytowym momencie swojej potęgi jako dowódcy bratrzyków.

\section{Bibliografia}

\section{Źródla rękopiśmienne}

Budapeszt, Magyar Nemzeti Levéltár Országos Levéltárában: Diplomatikai Levéltár 15279, 15307, 30851, 64882, 64883, 69015; Diplomatikai Fényképgyüjtemény 94486, 213134, 213704, 214073, 214253, 214339, 250009.

\section{Źródła drukowane}

Akta grodzkie i ziemskie z czasów Rzeczypospolitej Polskiej z Archiwum tzw. Bernardyńskiego we Lwowie w skutek fundacyi śp. Alexandra hr. Stadnickiego. T. 4. Wyd. K. Liske. Lwów 1873; T. 9. Wyd. K. Liske. Lwów 1883; T. 12. Wyd. K. Liske. Lwów 1887.

Chalupecki V.: Středověké listy ze Slovenska. Sbirka listi̊ a listin, psaných jazykem národném. Praha 1937.

Codex epistolaris saeculi decimi quinti. [T. 1]: 1384-1492: ex antiquis libris formularum, corpore Naruszeviciano, autographis archivistique plurimis collectus opera Augusti Sokotowski, Josephi Szujski. Pars 2. Kraków 1876.

${ }^{124}$ S. Kovačevičová: Človek a svet. Na obrazoch od stredoveku až nap rah súčastnosti. Bratislava 2006, s. 61. 
Decreta Regni Hungariae-Gesetze und verordnungen ungarns 1301-1457. Hrsg. F. Döry, G. Bonis, V. Bácskai. Budapest 1976.

Dekády uhorských dejín Antonia Bonfiniho. V: Pramene $k$ dejinám Slovenska a Slovákov. 6: Pod osmanskou hrozbou. Ed. P. Dvořák. Bratislava 2005.

Dokumenty polskie z archiwów dawnego Królestwa Węier. T. 1: (Do 1450 r.). Wyd. S. Sroka. Kraków 1998.

Joannis Dlugossi Annales seu cronicae incliti Regni Poloniae. Lib. 11-12. Ed. K. Baczkowski. Varsaviae 2001; lib. 12: 1462-1480. Ed. K. Baczkowski. Cracoviae 2005.

Kronika Jána z Turca. Preložil J. Sopko. Bratislava 2018.

Starodawne prawa polskiego pomniki. T. 2: Z ksiąg rękopiśmiennych dotąd nieużytych główniéj zaś z ksiag dawnych sądowych ziemskich i grodzkich Ziemi Krakowskiej. Wyd. A.Z. Helcel. Kraków 1870.

Supplementum analectorum terre Scepusiensis. Pars 2. Coll. M.S. Chmauk. Szepesváraljae 1889.

Tomáš Pešina z Čechorodu: Mars Moravicus. Praha 1677.

\section{Opracowania}

Baczkowski K.: Przectaw z Dmosic (Dmoszyc) h. Ostoja. W: Polski słownik biograficzny. T. 28. Wrocław-Warszawa-Kraków 1984-1985.

Bartl J.: Vztáah Jána Jiskru a Jána Huňadyho. V: Husiti na Slovensku. Zborník príspevkov z konferencie. Zodp. red. I. Kaczarová. Lučenec 2001.

Boniecki A.: Herbarz polski. Wiadomości historyczno-genealogiczne o rodach szlacheckich. T. 9. Warszawa 1907.

Čaplovič P.: Oravský zámok. Martin 1967.

Czwojdrak B.: Dziersław z Rytwian — rzekomy husyta polski. „Teki Krakowskie” 1999, T. 10.

Dąbrowski J.: Władysław I Jagiellończyk na Węgrzech (1440-1444). Oświęcim 2014.

Dvořáková D.: Stredoveké hrady na Slovensku: Život, kultúra, spoločnost'. Bratislava 2017.

Dyrlaga P.: Co wiemy o dziejach Starego Żywca w XV-XVI wieku? „Gronie” 2013, nr 13.

Floreková I.: Pol'ské vplyvy $v$ dejinách Oravského panstva a hradu. „Zborník Oravského muzea" 2010, č. 27.

Gácsová A.: Boje Mateja I. proti Jánovi Jiskrovi z Brandýsa a bratrikom v rokoch 1458-1467. „Historický Časopis“ 1977, č. 25.

Gawęda S.: Możnowładztwo małopolskie w XIV i w pierwszej połowie XV wieku. Kraków 1966.

Harčár P.: Bratrícke pevnôstky na východnom Slovensku. V: Husiti a bratríci na Slovensku. Ed. P. Žarnovský. Červený Kláštor-Kežmarok—Stará L'ubovňa 2016.

Husiti a bratríci na Slovensku. Ed. P. Žarnovský. Červený Kláštor-Kežmarok-Stará Lubovňa 2016.

Hyroš S.: Zamok Lykava a jeho pani, pot’ahom na državie, Lyptov a okolie. Martin 1876.

Jireček H.: Ján Jiskra z Brandýsa. „Slovesnost““ 1865, 3.

Jurok J.: Čeští husitští a katoličtí kondotiéři z Moravy na Slovensku v 15. století (obdobi bratříkư). „Vojenská história“ 2005, č. 4.

Kerekeš J.: Hrady Trenčianského Považia. „Letopis Matice Slovenskej“ 1867, roč. 3-4, zv. 1.

Kiryk F.: Komorowski Mikołaj. W: Polski słownik biograficzny. T. 13. Wrocław-WarszawaKraków 1967-1968. 
Kiryk F.: Komorowski Piotr. W: Polski słownik biograficzny. T. 13. Wrocław-WarszawaKraków 1967-1968.

Kovačevičová S.: Človek a svet. Na obrazoch od stredoveku až nap rah súčastnosti. Bratislava 2006.

Kurtyka J.: Polscy starostowie na Spiszu w XV i 1 polowie XVI w. „Acta Universitatis Nicolai Copernici. Historia" 1992, nr 26 (240).

Marszałek J.: Katalog grodzisk i zamków w Karpatach. Warszawa 1993.

Mišík M.: Husiti na Slovensku. Banská Bystrica 1928.

Morawski S.: Sądecczyzna za Jagiellonów z miasty spiskiemi i księstwem oświęcimskiem. T. 2. Kraków 1865.

Oslanský F.: Portrét Jána Jiskru z Brandýsa. V: Husiti na Slovensku: Zborník referátov z konferencie pri príleţitosti 550. výročia bitky pri Lučenci. Ed. I. Kaczarová. Lučenec 2011.

Oslanský F.: The Role of John Jiskra in the History of Slovakia. "Human Affairs" 1996, no 6.

Papajík D.: Ladislav Pohrobek: (1440-1457): uherský a český král. České Budějovice 2016.

Plewczyński M.: Wojny Jagiellonów z wschodnimi i poludniowymi sąsiadami Królestwa Polskiego w XV wieku. Siedlce 2005.

Rafacz J.: Dzieje i ustrój Podhala Nowotarskiego za czasów dawnej Rzeczypospolitej Polskiej. Warszawa 1935.

Rączka Z.: Archiwalia żywieckie w Archives nationales w Paryżu. „Karta Groni” 1991, nr 16.

Rączka Z.: Żywiec. Rys historyczny od powstania miasta do 1918 roku. Żywiec 1997.

Rozbiór krytyczny Annalium Poloniae Jana Dlugosza z lat 1385-1444. T. 1. Oprac. S. Gawęda, pod kier. J. Dąbrowskiego. Wrocław 1961.

Sasinek F.: Slovanski válečníci v Uhorsku XV-XVII. storočia (Ján Iskra). „Letopis Matice Slovenskej“ 1872, roč. 9, č. 1 .

Sikora F.: Mikołaj Ossoliński h. Topór. W: Polski stownik biograficzny. T. 24. Wrocław 1979.

Sikora F.: Mikołaj Pieniażek z Witkowic herbu Jelita. W: Polski słownik biograficzny. T. 26. Kraków-Wrocław 1981.

Sikora F.: Mszański zespół osadniczy w średniowieczu. W: Ojczyzna bliższa i dalsza. Studia historyczne ofiarowane Feliksowi Kirykowi w sześćdziesiąta rocznicę urodzin. Red. J. Chrobaczyński, A. Jureczko, M. Śliwa. Kraków 1993.

Špirko J.: Husiti, jiskrovci a bratríci v dejínách Spiša (1431-1462). Spišská Kapitula 1937.

Sroka S.A.: Komorowscy z Żywca. Przyczynki genealogiczne z XV wieku. „Gronie: historia — kultura - sztuka: wydawnictwo poświęcone Żywiecczyźnie i Beskidom” 2006, nr 1.

Sroka S.A.: Skrzyński Włodek. W: Polski słownik biograficzny. T. 38. Warszawa-Kraków 1998.

Sroka S.A.: Średniowieczny Bardiów i jego kontakty z Małopolską. Kraków 2010.

Tóth-Szabó P.: A cseh-huszita mozgalmak és uralom története Magyarországon. Budapest 1917.

Uličný F.: Šlachtic Pongrác zo Svätého Mikuláša - najvýznamnejši slovenský vojak a politik v 15. storočí. „Vojenská história: Časopis pre vojenskú históriu, múzejníctvo a archívnictvo“" 2017, č. 2.

Úradník J.: Husiti a Jan Jiskra z Brandýsa vdejinách stredného Slovenska. Bakalárska diplomová práca, vedúci prace: P. Boček, 2014.

Urbanek R.: Konec Ladislava Pohrobka. Praha 1924.

Żabiński G.: Działalność braci Piotra i Mikołaja Komorowskich na Górnych Węgrzech w latach 1440—1457 (w świetle badań w Archiwum Bardowskim). „Studia Historyczne” 2000, nr 43.

Żabiński G.: Działalność braci Piotra i Mikołaja Komorowskich na Górnych Wegrzech w okresie rządów Macieja Korwina. W: „Zeszyty Naukowe Uniwersytetu Jagiellońskiego”. Prace historyczne, nr 128. Kraków 2001. 
Karol Krajewski

\section{Once More on the Activity of Piotr and Mikołaj Komorowski in Upper Hungary in the Fifteenth Century}

Summary

Karol Krajewski takes up the subject of the activity of Piotr and Mikołaj Komorowski of the Korczak coat of arms in the northern part of the Kingdom of Hungary in the fifteenth century. Their activity is closely related to the topic of Upper Hungary in this period, a topic that has been discussed many times since the beginning of modern historiography, especially in Slovak and Polish historiography. Krajewski's article is an attempt to assess the value of this research.

Krajewski focuses on the activity of Piotr and Mikołaj Komorowski in the Hungarian territories in the years from c. 1440 to c. 1480. Describing the activity of Mikołaj Komorowski, Krajewski points to, among other things, his active participation, in the capacity of a military commander, in the civil war in Hungary on the side of Władysław III of Poland (Władysław Jagiellończyk) and his conflict with the bishop of Kraków Zbigniew Oleśnicki for the Spiš starostwo (county). Among the activities of Piotr Komorowski, Krajewski discusses the gradual building of his position in the area of Upper Hungary during the life of Władysław III and in the period after this king's death, his rivalry and cooperation with other powerful nobles in this region, his involvement in the events related to the activity of the so-called bratrzyks, and his participation in the conflicts between Casimir IV Jagiellon (Kazimierz Jagiellończyk) and Maciej Korwin.

Keywords: Piotr and Mikołaj Komorowscy, Żywiec, Spiš, Orava, Liptov

Karol Krajewski

\section{Ergänzende Anmerkungen zur Tätigkeit von Piotr und Mikołaj Komorowski} in Oberungarn im 15. Jahrhundert

Zusammenfassung

Der Autor des Artikels greift das Thema der Tätigkeit von Piotr und Mikołaj Komorowski mit dem Wappen von Korczak im nördlichen Teil des Königreichs Ungarn im 15. Jahrhundert auf. Diese Tätigkeit steht in engem Zusammenhang mit dem damaligen Oberungarn, das heißt mit einem Thema, das seit Beginn der modernen Geschichtsschreibung bereits mehrmals behandelt wurde, vor allem in der slowakischen und polnischen Geschichtsschreibung. In dem Artikel wird ein Versuch unternommen, den bisherigen Forschungsstand zu verifizieren.

Der Autor konzentriert sich auf die Tätigkeit von Piotr und Mikołaj Komorowski in den ungarischen Territorien in den Jahren von etwa 1440 bis etwa 1480. Bei der Beschreibung von Mikołaj Komorowskis Aktivitäten verweist er unter anderem auf seine aktive Teilnahme als Oberbefehlshaber am Bürgerkrieg in Ungarn auf der Seite von Władysław III. von Warna oder auf den Konflikt des Magnaten mit dem Bischof von Krakau - Zbigniew Oleśnicki, um die Starostei Zips. Zu den Aktivitäten von Piotr Komorowski gehörten: der allmähliche 
Aufbau seiner Position in Oberungarn zu Lebzeiten von König Władysław III. von Warna und nach dessen Tod, Rivalität und Zusammenarbeit mit anderen, in dieser Region tätigen Magnaten, Beteiligung an Ereignissen verbunden mit der Tätigkeit der so genannten „Bratschiki“" und Teilnahme an Konflikten zwischen Kasimir dem Jagiellonen und Matthias Corvinus.

Schlüsselwörter: Piotr und Mikołaj Komorowski, Saybusch, Zips, Arwa, Liptau 